\title{
New oral anticoagulants: key messages for clinicians
}

\author{
Matteo Giorgi-Pierfranceschi, ${ }^{1}$ Chiara Cattabiani, ${ }^{1}$ Francesco Dentali ${ }^{2}$ \\ ${ }^{1}$ Emergency Department, Hospital of Val d'Arda, Piacenza, Italy; ${ }^{2}$ Internal Medicine Department, University of Insubria, \\ Varese, Italy
}

\begin{abstract}
New oral anticoagulants are an effective and safe alternative to vitamin $\mathrm{K}$ antagonists in many fields of clinical practice. The use of the direct inhibitors of activated Factor II (dabigatran) and activated Factor X (apixaban and rivaroxaban), both in patients with non-valvular atrial fibrillation (NVAF) and those with acute venous thromboembolism (VTE), is of great interest for internal medicine physicians. This paper aims to give practical guidance on management (starting therapy, follow up and bleeding complications) of patients treated with dabigatran, rivaroxaban or apixaban for NVAF or acute VTE providing practical tables concerning the phases of therapy, management of complications, drug interaction and dose adjustment if renal impairment occurs.
\end{abstract}

\section{Introduction}

Vitamin K antagonists (VKA) interfere with the coagulation cascade through inhibition of Factors IIVII-IX-X. VKA have a slow onset of anticoagulant action, a long half-life, multiple food and drug interactions, and a very narrow therapeutic window outside of which the thrombotic and bleeding risk increases exponentially. These characteristics mean that VKA require periodical monitoring of the international normalized ratio (INR) for dose adjustments. These features have determined the exclusion of a large portion (approx. 50\%) of all eligible subjects from anticoagulant therapy.

New oral anticoagulants (NOAC) have been stud-

Correspondence: Matteo Giorgi-Pierfranceschi, Emergency Department, Hospital of Val d'Arda, via Roma 35, 29017 Fiorenzuola d'Arda (PC), Italy.

Tel.: +39.0523.989799.

E-mail: m.giorgi@ausl.pc.it

Key words: new oral anticoagulants, internal medicine, management checklist.

Conflict of interests: the authors declare no potential conflict of interests.

Received for publication: 11 November 2013.

Revision received: Not required.

Accepted for publication: 4 December 2013.

This work is licensed under a Creative Commons Attribution NonCommercial 3.0 License (CC BY-NC 3.0).

CCopyright M. Giorgi-Pierfranceschi et al., 2013

Licensee PAGEPress, Italy

Italian Journal of Medicine 2013; 7(s8):74-84

doi:10.4081/itjm.2013.s8.74 ied in several randomized controlled trials, enrolling over 100,000 patients. ${ }^{1-15}$ Potential indications for NOAC include primary and secondary prevention of arterial and venous thromboembolic events. So far, these drugs (or some of them) have proven their effectiveness and safety in the prevention of venous thromboembolism (VTE) in major orthopedic surgery, ${ }^{14}$ in the secondary prevention of acute coronary syndromes (ACS), ${ }^{15}$ non-valvular atrial fibrillation (NVAF) $)^{1-4}$ and $\mathrm{VTE}^{5-10}$ (Tables A1 and A2). In particular, NVAF and VTE are frequently encountered in clinical practice by clinicians and these will receive particular attention in this paper.

The most attractive features of NOAC concern the direct and selective inhibition of a single coagulation factor (thrombin or Factor X), the fast onset of anticoagulant activity, the predictable effect, the few food and drug interactions, and the short plasma halflife. Thanks to these characteristics, the NOAC can be used at fixed dose, and they do not usually need to be monitored.

Thanks to these characteristics, and to the favorable results of phase III clinical trials, in particular in patients with NVAF and VTE, the prescription of NOAC in clinical practice is expected to increase.

This paper provides a summary of the information provided in the papers that make up this monographic issue in order to give some practical advice on management of patients treated with these new agents.

\section{Initial treatment}

Before introducing a treatment with NOAC, clinicians should check the following factors (Table A3).

- Clinical indications (NVAF, VTE): evaluation of the thromboembolic risk in patients with atrial fibrillation (with the CHADS-VASC2 score) (Table A4). 
- Ongoing treatment with other antithrombotic agents (VKA unfractionated heparin (UFH), low molecular weight heparins (LMWH), fondaparinux, warfarin, NOAC) or antiplatelet drugs and concomitant treatment with drugs that may alter the efficacy and safety of NOAC.

- Presence of absolute or relative contraindications to anticoagulant therapy: inherited or acquired bleeding disorders, severe uncontrolled hypertension, active or recent gastrointestinal ulcers, vascular retinopathy, recent intracranial or intracerebral hemorrhage, vascular abnormalities of the central nervous system (CNS), recent neurosurgery or ophthalmic surgery, bronchiectasis, or a history of pulmonary hemorrhage.

- Presence of absolute or relative contraindications to NOAC therapy: prosthetic heart valves, pulmonary emboli (PE) hemodynamically instable candidates for thrombolysis.

- Evaluation of the bleeding risk (HAS-BLED score in patients with AF) (Table A5).

- Evaluation of routine laboratory tests: coagulation (aPTT, PT) complete blood cell count (BCC), hepatic function (excluding patients with severe hepatic impairment, defined as bilirubin $>2$ times upper limit of normal (ULN), in association with AST/ALT/ALP $>3$ times ULN) and renal function (Cockroft method to calculate creatinine clearance) (Table A6).

- Identification of the appropriate dosage (Tables A7 and A8) according to the data sheet for the selected drug, patient characteristics and disease type. For patients with VTE, only Xa-inhibitors (rivaroxaban and apixaban) have been approved for acute treatment with a dual intensity approach (Table A8). Elderly subjects (>80 years of age) represent a particular population in which both cardioembolic and bleeding risk are increased, but few data are currently available regarding the use of NOAC in this kind of patients (data transferability).

The systematic assessment of all these points could help the internist to identify those patients who could benefit from NOAC treatment.

\section{Monitoring}

The pharmacological characteristics of NOAC allow the use of standardized dosages without the need for routine monitoring with coagulation tests. In general, only complete BCC, renal (plasma creatinine, creatinine clearance, Cockroft-Gault method), and hepatic function (indexes of hepatic cytolysis) are useful for monitoring patients on NOAC therapy.

According to current guidelines, ${ }^{16,17}$ these tests should be performed before initiation of therapy, after the first three months of therapy, and then every six months. Monitoring should be planned more frequently in subjects with risk factors such as age over 80 years or altered renal function (Table A9).

Furthermore, at each visit the following points should be considered.

- Concomitant administration of drugs that can increase or decrease the anticoagulant effect of these drugs or that contraindicate NOAC coadministration.

- Adherence to the therapy (drug compliance): calculating the number of tablets taken in the period between two consecutive prescriptions and checking the boxes of medication used.

- Occurrence of bleeding or thromboembolic events during treatment.

- Reevaluation of indication to continue anticoagulant therapy and of the patient's risk of bleeding.

\section{Management of bleeding events}

Bleeding events are certainly the most feared complication of anticoagulant treatment. An appropriate clinical approach is mandatory according to the bleeding severity (e.g. minor, major, life-threatening). In case of any bleeding complications, it may be useful to collect information on dosage and time of last intake of the drug. Furthermore, in all the major and lifethreatening bleeding complications, the clinician should collect information on concomitant pharmacotherapy, paying particular attention to any new therapies that have been introduced that may interfere with the NOAC, such as macrolide antibiotics, antifungal agents, antiarrhythmics, antidepressants, antiepileptics, non-steroid anti-inflammatory drugs (NSAIDs) etc. (Table A10). Evaluation of renal function with creatinine clearance calculation (in particular in patients receiving dabigatran), hepatic function and complete BCC should be performed. Finally, local measurement for assessment of hemostasis failure should be considered.

\section{Minor bleeding}

These are hemorrhagic adverse event without the characteristics of major and life-threatening bleedings. In this case, drug intake may be postponed or one dose of the drug may be skipped.

\section{Major bleeding}

According to the widely accepted International Society on Thrombosis and Hemostasis (ISTH) definition, bleeding is classified as major if it was overt and associated with a decrease in the hemoglobin level of $2 \mathrm{~g} / \mathrm{dL}$ or more, required the transfusion of 2 or more units of blood, occurred into a critical site (retroperitoneal, intraocular, hemoperitoneum, hemothorax, 
spinal hematoma, hematemesis and melena, hemopericardium, hemarthrosis of the large joints), or contributed to death ${ }^{18}$ (Table A11).

In addition to standard supportive measurements (such as mechanical compression, surgical hemostasis, fluid replacement, and other hemodynamic support), when a major bleeding complication occurs, the clinician must withhold anticoagulant therapy. Blood volume repletion and restoration of normal platelet count (in case of thrombocytopenia $\leq 60 \times 10^{9} / \mathrm{L}$ or thrombopathy) should be considered. Furthermore, since dabigatran is potentially dialyzable (although clinical experience is limited), dyalisis should be considered in patients treated with this drug (Table A12).

\section{Life-threatening bleeding}

Intracranial hemorrhage or other bleeding events characterized by a decrease in hemoglobin of $5 \mathrm{~g} / \mathrm{dL}$ or more, requiring transfusion of 4 units or more of packed red blood cells, and bleeding events associated with shock and hypoperfusion or requiring surgery should be considered potentially life-threatening. In this case, in addition to the standard supportive measures, it is mandatory to restore normal blood coagulation as soon as possible using, if available, (four factors) intravenous (i.v.) prothrombin concentrates (PCCs) at a dose of $50 \mathrm{IU} / \mathrm{kg}{ }^{19,20}$

In case of treatment failure, administration of activated prothrombin concentrate (FEIBA, Baxter) containing Factors II, VII, IX, $\mathrm{X}$ in inactive and active forms at a dose of $50 \mathrm{IU} / \mathrm{kg}$ (up to $200 \mathrm{IU} / \mathrm{kg} /$ day) or administration of recombinant activated Factor VII (rFVIIa: Novo Seven; 90-100 $\mu \mathrm{g} / \mathrm{kg}$ ) should be considered, although use of these compounds may be associated with a high risk of thromboembolic complications. ${ }^{18,21}$

Tranexamic acid at a dose of $10-30 \mathrm{mg} / \mathrm{kg}$ (i.v.) may be considered as a supportive measure, although there are no clinical data on the use of this compound in patients receiving $\mathrm{NOAC}^{22}$ (Table A13).

In the future, since an increase in the use of NOAC is expected, protocols for the management of adverse bleeding events (periodically revised in consideration of new information from literature) should be established in each hospital. Strategies for switching to and from NOAC should also be put in place (Table A14). ${ }^{17,23}$

\section{Conclusions}

New oral anticoagulants are a new treatment option particularly favorable for the management of patients with NVAF and acute VTE. Risk of thromboembolic and hemorrhagic complication should be evaluated in each patient before the intro- duction of an NOAC. Due to their relatively short half-life, compliance to therapy appears to be crucial, and an incorrect drug intake may result in therapeutic failure or in the occurrence of severe and potentially life-threatening adverse events. Clinician expertise in treating and monitoring acute and chronic diseases may be central to the management of these new anticoagulant drugs, helping to increase the benefits and to reduce complications of this therapy.

\section{References}

1. Granger CB, Alexander JH, McMurray JJ, et al. Apixaban versus warfarin in patients with atrial fibrillation. $\mathrm{N}$ Engl J Med 2011;365:981-92.

2. Connolly SJ, Eikelboom J, Joyner C, et al. Apixabanin patients with atrial fibrillation. N Engl J Med 2011;364: 806-17.

3. Connolly SJ, Ezekowitz MD, Yusuf S, et al. Dabigatran versus warfarin in patients with atrial fibrillation. N Engl J Med 2009;361:1139-51.

4. Patel MR, Mahaffey KW, Garg J. Rivaroxaban versus warfarin in nonvalvular atrial fibrillation. N Engl J Med 2011;365:883-91.

5. Agnelli G, Buller HR, Cohen A, et al. Apixaban for extended treatment of venous thromboembolism. New Engl J Med 2013;368:699-708.

6. Schulman S, Kakkar AK, Schellong SM, et al. A Randomized trial of dabigatran versus warfarin in the treatment of acute venous thromboembolism (RE-COVER II). ASH Annual Meeting, San Diego, CA, USA, 2011.

7. Schulman S, Kearon C, Kakkar AK, et al. Dabigatran versus warfarin in the treatment of acute venous thromboembolism. New Engl J Med 2009;361:2342-52.

8. Buller HR, Prins MH, Lensin AW, et al. Oral rivaroxaban for the treatment of symptomatic pulmonary embolism. New Engl J Med 2012;366:1287-97.

9. Bauersachs R, Berkowitz SD, Brenner B, et al. Oral rivaroxaban for symptomatic venous thromboembolism. New Engl J Med 2010;363:2499-510.

10. Romualdi E, Donadini MP, Ageno W. Oral rivaroxaban after symptomatic venous thromboembolism: the continued treatment study (EINSTEIN-Extension study). Expert Rev Cardiovasc Ther 2011;9:841-4.

11. Goldhaber SZ, Leizorovicz A, KakkarAK, et al. Apixaban versus enoxaparin for thromboprophylaxis in medically ill patients. N Engl J Med 2011;365:2167-77.

12. Cohen AT, Spiro TE, Büller HR, et al. Extended-duration rivaroxaban thromboprophylaxis in acutely ill medical patients: MAGELLAN study protocol. J Thromb Thrombolysis 2011;31:407-16.

13. Cohen AT, Spiro TE, Büller HR, et al. Rivaroxaban for thromboprophylaxis in acutely ill medical patients. $\mathrm{N}$ Engl J Med 2013;368:513-23.

14. Galanis T, Merli GJ. New oral anticoagulants: prevention of VTE in phase III studies in total joint replacement surgery and the hospitalized medically-ill patients. J Thromb Thrombolysis 2013;36:141-8.

15. Mega JL, Braunwald E, Mohanavelu S, et al. Rivaroxaban versus placebo in patients with acute coronary syndromes (ATLAS ACS-TIMI 46): a randomised, 
double-blind, phase II trial. Lancet 2009;374:29-38.

16. Camm AJ, Lip GY, De Caterina R, et al. 2012 focused update of the ESC Guidelines for the management of atrial fibrillation. Eur Heart J 2012;33:2719-47.

17. Heidbuchel H, Verhamme P, Alings $M$, et al. EHRA practical guide on the use of new oral anticoagulants in patients with non-valvular atrial fibrillation: executive summary. Eur Heart J 2013;34:2094-106.

18. Schulman S, Kearon C; Subcommittee on Control of Anticoagulation of the Scientific and Standardization Committee of the International Society on Thrombosis and Haemostasis. Definition of major bleeding in clinical investigations of antihemostatic medicinal products in nonsurgical patients. J Thromb Haemost 2005;3:692-4.

19. Eerenberg ES, Kamphuisen PW, Sijpkens MK, et al. Reversal of rivaroxaban and dabigatran by prothrombin complex concentrate: a randomized, placebo-controlled, crossover study in healthy subjects. Circulation 2011;124:1573-9.

20. Marlu R, Hodaj E, Paris A, et al. Effect of nonspecific re- versal agents on anticoagulant activity of dabigatran and rivaroxaban. A randomised crossover ex vivo study in healthy volunteers. Thromb Haemos 2012;108:217-24.

21. van Ryn J, Ruehl D, Priepke H, et al. Reversibility of the anticoagulant effect of high doses of the direct thrombin inhibitor dabigatran, by recombinant factor VIIa or activated prothrombin complex concentrate. Haematologica 2008;93:148.

22. Shakur H, Roberts R, Bautista R, et al. Effects of tranexamic acid on death, vascular occlusive events, and blood transfusion in trauma patients with significant haemorrhage (CRASH-2): a randomised, placebo-controlled trial. Lancet 2010;376:23-32.

23. Palareti G, Ageno W, Ferrari A, et al. Clinical management of rivaroxaban-treated patients. Expert Opin Pharmacother 2013;14:655-67.

24. Agnelli G, Becattini C, Franco L. New oral anticoagulants for the treatment of venous thromboembolism. Best Pract Res Clin Haematol 2013;26:151-61. 


\section{Appendix}

\section{New oral anticoagulants: key messages for clinicians}

\begin{tabular}{|l|c|c|c|c|c|c|}
\hline Characteristics & \multicolumn{2}{|c|}{ ARISTOTELE } & \multicolumn{2}{c|}{ RE-LY } & ROCKET -AF \\
\hline & Apixaban & Warfarin & Dabigatran & Warfarin & Rivaroxaban & Warfan \\
\hline & & & & & \\
\hline
\end{tabular}

Table A1. Randomized controlled trials comparing NOACs and vitamin K antagonists in patients with non-valvular atrial fibrillation.

\begin{tabular}{|c|c|c|c|}
\hline NOAC & Dabigatran & Rivaroxaban & Apixaban \\
\hline Phase III study & $\begin{array}{l}\text { RE-COVER } \\
\text { RE-COVER II }\end{array}$ & $\begin{array}{l}\text { EINSTEIN DVT } \\
\text { EINSTEIN PE }\end{array}$ & AMPLIFY \\
\hline Treatment & $\begin{array}{l}\text { Enoxaparin/dabigatran } v s \\
\text { enoxaparin/warfarin }\end{array}$ & $\begin{array}{l}\text { Rivaroxaban } \\
v s \text { enoxaparin/VKAs }\end{array}$ & $\begin{array}{l}\text { Apixaban } \\
v s \text { enoxaparin/warfarin }\end{array}$ \\
\hline Design & Double blind & Open-label & $\begin{array}{l}\text { Double blind double- } \\
\text { dummy }\end{array}$ \\
\hline No. patients & $\begin{array}{lr}\text { RECOVER } & \text { no. } 2539 \\
\text { RECOVER II } & \text { no. } 2589\end{array}$ & $\begin{array}{ll}\text { EINSTEIN DVT } & \text { no. } 3449 \\
\text { EINSTEIN PE } & \text { no. } 4832\end{array}$ & AMPLIFY 5395 \\
\hline Dose (mg) & $\begin{array}{l}\text { LWMH (100U/kg bid) } \\
\text { Days 1-7 } \\
\text { Dabigatran } 150 \text { bid from } \\
\text { Day } 8\end{array}$ & $\begin{array}{l}\text { Rivaroxaban } 15 \mathrm{mg} \text { bid Days } \\
1-21 \text { and } 20 \mathrm{mg} \text { bid from Day } \\
22\end{array}$ & $\begin{array}{l}\text { Apixaban } 10 \mathrm{mg} \text { bid } \\
\text { Days } 1-7 \text { and } 5 \mathrm{mg} \text { bid } \\
\text { from Day } 8\end{array}$ \\
\hline Duration & $\begin{array}{l}\text { RE-COVER } 6 \text { months } \\
\text { RE-COVER II } 6 \text { months }\end{array}$ & $\begin{array}{l}\text { EINSTEIN DVT } 3-6 \text { or } 12 \\
\text { months } \\
\text { EINSTEIN PE } \\
\text { months }\end{array}$ & AMPLIFY 6 months \\
\hline
\end{tabular}

Table A2. Randomized controlled trials comparing NOACs and vitamin K antagonists in patients with acute venous thromboembolism. Modified from Agnelli et al., 2013.24 
- Check indication to anticoagulation (CHA2DS2VASC in AF patients)

- Assess bleeding risk stratification (HAS BLED)

- Calculate creatinine clearance

- Choice of anticoagulant and dosing regimen

- Concomitant medications

- Patient education

- Assess risk stratification in PE patients

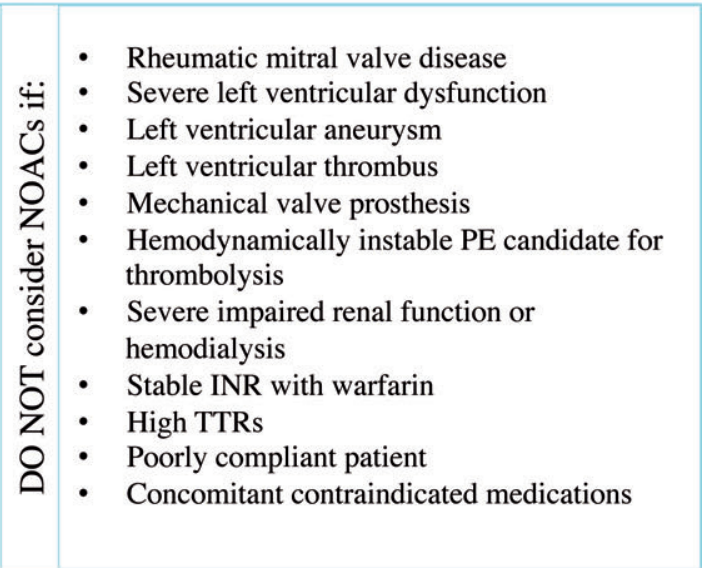

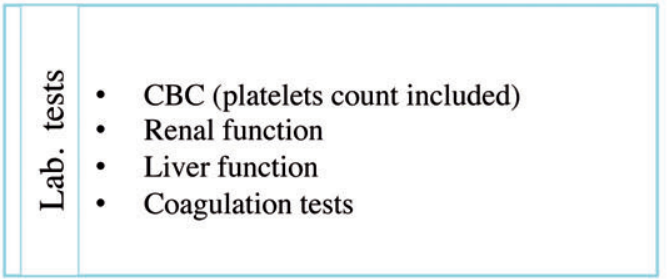

\begin{tabular}{|l|l|}
\hline & Strong preference expressed by the \\
& patient \\
& -
\end{tabular}

Table A3. Initial treatment.

\begin{tabular}{|c|c|c|}
\hline \multirow{6}{*}{ 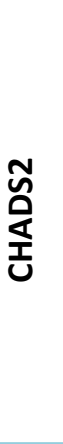 } & Risk factors & Score \\
\hline & Congestive heart failure & 1 \\
\hline & Hypertension & 1 \\
\hline & Age $\geq 75$ & 1 \\
\hline & Diabetes mellitus & 1 \\
\hline & Stroke or TIA & 2 \\
\hline
\end{tabular}

\begin{tabular}{|l|c|}
\hline Score & Cardioembolic risk \%/year (CI) \\
\hline 0 & $1.9(1.2-3.0)$ \\
\hline 1 & $2.8(2.0-3.8)$ \\
\hline 2 & $4.0(3.1-5.1)$ \\
\hline 3 & $5.9(4.6-7.3)$ \\
\hline 4 & $8.5(6.3-11.1)$ \\
\hline 5 & $12.5(8.2-17.5)$ \\
\hline 6 & $18.2(10.5-27.4)$ \\
\hline
\end{tabular}

\begin{tabular}{|c|c|c|c|}
\hline \multirow{3}{*}{ 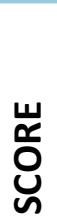 } & & Risk factors & Score \\
\hline & $\mathrm{C}$ & Congestive heart failure & 1 \\
\hline & $\mathrm{H}$ & Hypertension & 1 \\
\hline \multirow{6}{*}{ 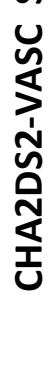 } & A & Age $\geq 75$ & 2 \\
\hline & $\mathrm{D}$ & Diabetes mellitus & 1 \\
\hline & $S$ & Stroke or TIA & 2 \\
\hline & V & Vascular disease (AMI, ACS, PAD) & 1 \\
\hline & A & Age $65-74$ year & 1 \\
\hline & Sc & Gender category & 1 \\
\hline
\end{tabular}

\begin{tabular}{|l|c|}
\hline Score & Cardioembolic risk \%/year $(\mathrm{CI})$ \\
\hline 0 & $0.78(0.58-1.04)$ \\
\hline 1 & $2.01(1.70-2.36)$ \\
\hline 2 & $3.71(3.36-4.09)$ \\
\hline 3 & $5.92(5.53-6.34)$ \\
\hline 4 & $9.27(8.71-9.86)$ \\
\hline 5 & $15.26(14.35-16.24)$ \\
\hline 6 & $19.74(18.21-21.41)$ \\
\hline 7 & $21.50(18.75-24.64)$ \\
\hline 8 & $22.38(16.29-30.76)$ \\
\hline 9 & $23.64(10.62-52.61)$ \\
\hline
\end{tabular}

Table A4. Cardioembolic risk stratification. 


\begin{tabular}{|l|l|l|l|}
\hline Risk factors & Score & Total Score & Bleeding risk \%/year \\
\hline Stroke/TIA & 1 & 0 & 1.13 \\
\hline Age $>$ 65 years & 1 & 1 & 1.02 \\
\hline $\begin{array}{l}\text { Prior major bleeding or } \\
\text { predisposition to bleeding }\end{array}$ & 1 & 2 & 1.88 \\
\hline $\begin{array}{l}\text { Hedication usage } \\
\text { predisposing to bleeding }\end{array}$ & 1 & 3 & 3.74 \\
\hline $\begin{array}{l}\text { History of alcohol use } \\
\text { Labile INR }\end{array}$ & 1 & 4 & 8.70 \\
\hline Liver disease & 1 & 5 & 12.50 \\
\hline Renal disease & 1 & 6 & $\ldots$ \\
\hline & 1 & 7 & $\ldots$ \\
\hline
\end{tabular}

Table A5. Bleeding risk stratification.

\begin{tabular}{|c|c|c|c|c|}
\hline & $\begin{array}{l}\mathrm{CrCl} \mathrm{mL} / \\
\min \end{array}$ & DABIGATRAN & APIXABAN & RIVAROXABAN \\
\hline $\begin{array}{l}\text { Fraction renal excretion of } \\
\text { absorbed dose }\end{array}$ & & $80 \%$ & $27 \%$ & $35 \%$ \\
\hline APPROVED FOR & & $\mathrm{CrCl} \geq 30 \mathrm{~mL} / \mathrm{min}$ & $\mathrm{CrCl} \geq 15 \mathrm{~mL} / \mathrm{min}$ & $\mathrm{CrCl} \geq 15 \mathrm{~mL} / \mathrm{min}$ \\
\hline NOT RECOMMENDED IF & & $\mathrm{CrCl}<30 \mathrm{~mL} / \mathrm{min}$ & $\mathrm{CrCl}<15 \mathrm{~mL} / \mathrm{min}$ & $\mathrm{CrCl}<15 \mathrm{~mL} / \mathrm{min}$ \\
\hline DOSING ADJUSTMENT & $\sqrt{n}$ & $\begin{array}{l}\text { - } \mathrm{CrCl} \geq 50 \mathrm{~mL} / \mathrm{min} \\
\mathrm{No} \text { adjustment: } 150 \mathrm{mg} / \mathrm{bid} \\
\\
\text { - } \mathrm{CrCl} 30-49 \mathrm{~mL} / \mathrm{min} \\
150 \mathrm{mg} \text { bid is possible or } \\
110 \mathrm{mg} \text { bid if recommended or } \\
\text { high risk of bleeding }\end{array}$ & $\begin{array}{l}\text { - Serum Creatinine }<1.5 \mathrm{mg} / \mathrm{dL} \\
\text { No adjustment: } 5 \mathrm{mg} \text { bid } \\
\mathrm{CrCl} 15-29 \mathrm{~mL} / \mathrm{min} \\
2.5 \mathrm{mg} \text { bid } \\
\text { Serum creatinine } \geq 1.5 \mathrm{mg} / \mathrm{dL} \text { in } \\
\text { combination with at least one of: } \\
-\quad \text { age } \geq 80 \text { years } \\
-\quad \text { weight } \leq 60 \mathrm{Kg} \\
-\quad \text { concomitant diltiazem } \\
2.5 \mathrm{mg} \text { bid }\end{array}$ & $\begin{array}{l}\mathrm{CrCl} \geq 50 \mathrm{~mL} / \mathrm{min} \\
\text { No adjustment: } 20 \mathrm{mg} \mathrm{qd} \\
\\
\mathrm{CrCl} 15-49 \mathrm{~mL} / \mathrm{min} \\
15 \mathrm{mg} \mathrm{qd}\end{array}$ \\
\hline \multirow{4}{*}{$\begin{array}{l}\text { ESTIMATED DRUG } \\
\text { HALF-LIVES IN } \\
\text { DIFFERENT STAGES OF } \\
\text { CKD (I-V) }\end{array}$} & $\begin{array}{l}\mathrm{CrCl} \geq 60 \\
\text { Stage I-II }\end{array}$ & $14 \mathrm{~h}$ & No data & $8.5 \mathrm{~h}(+44 \%)$ \\
\hline & $\begin{array}{l}\text { CrCl 30-60 } \\
\text { Stage III }\end{array}$ & $18 \mathrm{~h}$ & No data & $9 \mathrm{~h}(+52 \%)$ \\
\hline & $\begin{array}{l}\mathrm{CrCl} 15-30 \\
\text { Stage IV }\end{array}$ & $28 \mathrm{~h}$ & No data & $9.5 \mathrm{~h}(+64 \%)$ \\
\hline & $\begin{array}{l}\mathrm{CrCl} \leq 30 \\
\text { Stage V }\end{array}$ & No data & No data & No data \\
\hline
\end{tabular}

Table A6. NOACs and chronic kidney disease. Modified from Heidbuchel et al., 2013. ${ }^{17}$ 


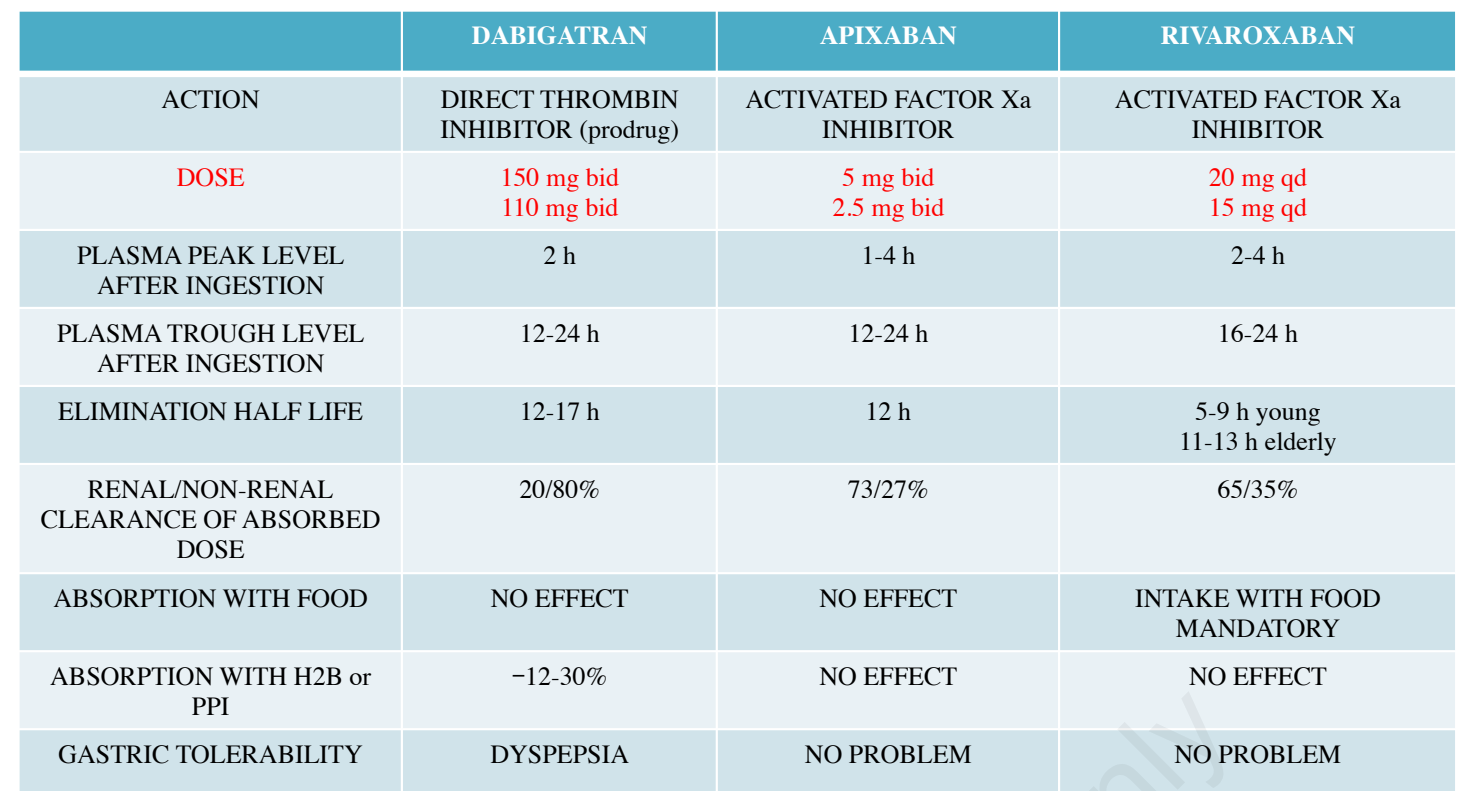

Table A7. NOACs approved for prevention and treatment of stroke and systemic embolism in non-valvular atrial fibrillation.

\begin{tabular}{|c|c|c|c|}
\hline & DABIGATRAN & APIXABAN & RIVAROXABAN \\
\hline ACTION & $\begin{array}{l}\text { DIRECT THROMBIN } \\
\text { INHIBITOR (pro-drug) }\end{array}$ & $\begin{array}{c}\text { ACTIVATED FACTOR Xa } \\
\text { INHIBITOR }\end{array}$ & $\begin{array}{c}\text { ACTIVATED FACTOR Xa } \\
\text { INHIBITOR }\end{array}$ \\
\hline $\begin{array}{l}\text { PROPHYLACTIC DOSE } \\
\text { (THR-KHR) }\end{array}$ & $220 \mathrm{mg}$ od & $2.5 \mathrm{mg}$ bid & $10 \mathrm{mg}$ od \\
\hline $\begin{array}{l}\text { THERAPEUTIC DOSE } \\
\text { (DVT-PE) }\end{array}$ & NA & $\begin{array}{l}10 \mathrm{mg} \text { bid Day } 1-7 \\
5 \mathrm{mg} \text { bid from Day } 8\end{array}$ & $\begin{array}{l}15 \mathrm{mg} \text { bid Day } 1-21 \\
20 \mathrm{mg} \text { from Day } 22\end{array}$ \\
\hline $\begin{array}{l}\text { PLASMA PEAK LEVEL } \\
\text { AFTER INGESTION }\end{array}$ & $2 \mathrm{~h}$ & $1-4 \mathrm{~h}$ & $2-4 \mathrm{~h}$ \\
\hline $\begin{array}{l}\text { PLASMA TROUGH LEVEL } \\
\text { AFTER INGESTION }\end{array}$ & $12-24 \mathrm{~h}$ & $12-24 \mathrm{~h}$ & $16-24 \mathrm{~h}$ \\
\hline ELIMINATION HALF LIFE & $12-17 \mathrm{~h}$ & $12 \mathrm{~h}$ & $\begin{array}{l}5-9 \mathrm{~h} \text { young } \\
11-13 \mathrm{~h} \text { elderly }\end{array}$ \\
\hline $\begin{array}{c}\text { RENAL/NON RENAL } \\
\text { CLEARANCE OF ABSORBED } \\
\text { DOSE }\end{array}$ & $20 / 80 \%$ & $73 / 27 \%$ & $65 / 35 \%$ \\
\hline ABSORPTION WITH FOOD & NO EFFECT & NO EFFECT & $\begin{array}{l}\text { INTAKE WITH FOOD } \\
\text { MANDATORY }\end{array}$ \\
\hline $\begin{array}{c}\text { ABSORPTION WITH H2B or } \\
\text { PPI }\end{array}$ & $-12-30 \%$ & NO EFFECT & NO EFFECT \\
\hline GASTRIC TOLERABILITY & DYSPEPSIA & NO PROBLEM & NO PROBLEM \\
\hline
\end{tabular}

Table A8. NOACs approved for prevention and treatment of venous thromboembolism. 


\begin{tabular}{|c|c|}
\hline 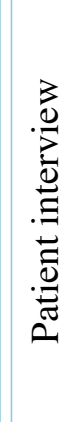 & $\begin{array}{l}\text { - } \text { Compliance } \\
\text { - Thromboembolic events } \\
\text { - } \text { Bleeding events } \\
\text { - Side effects } \\
\text { - Hospitalization } \\
\text { - Concomitant medication } \\
\text { - Consider PPI } \\
\text { - Re-assess bleeding and } \\
\text { thrombotic risk score }\end{array}$ \\
\hline
\end{tabular}

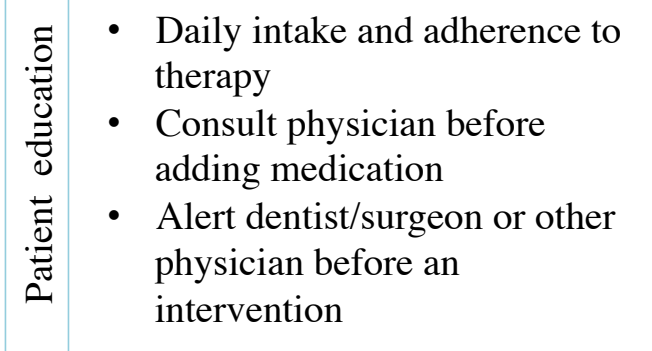
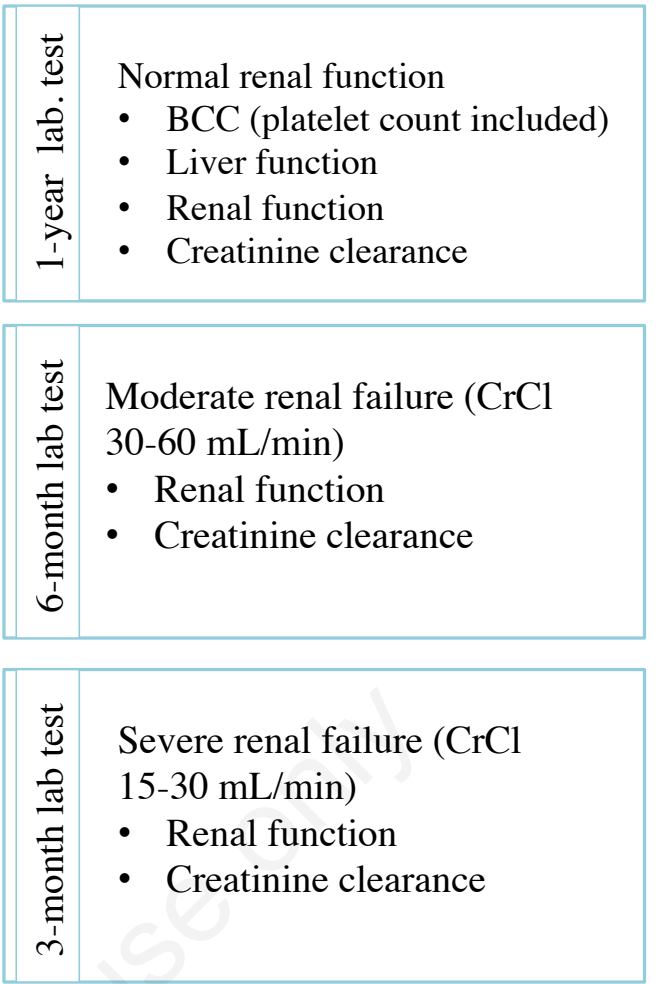

Table A9. Monitoring.

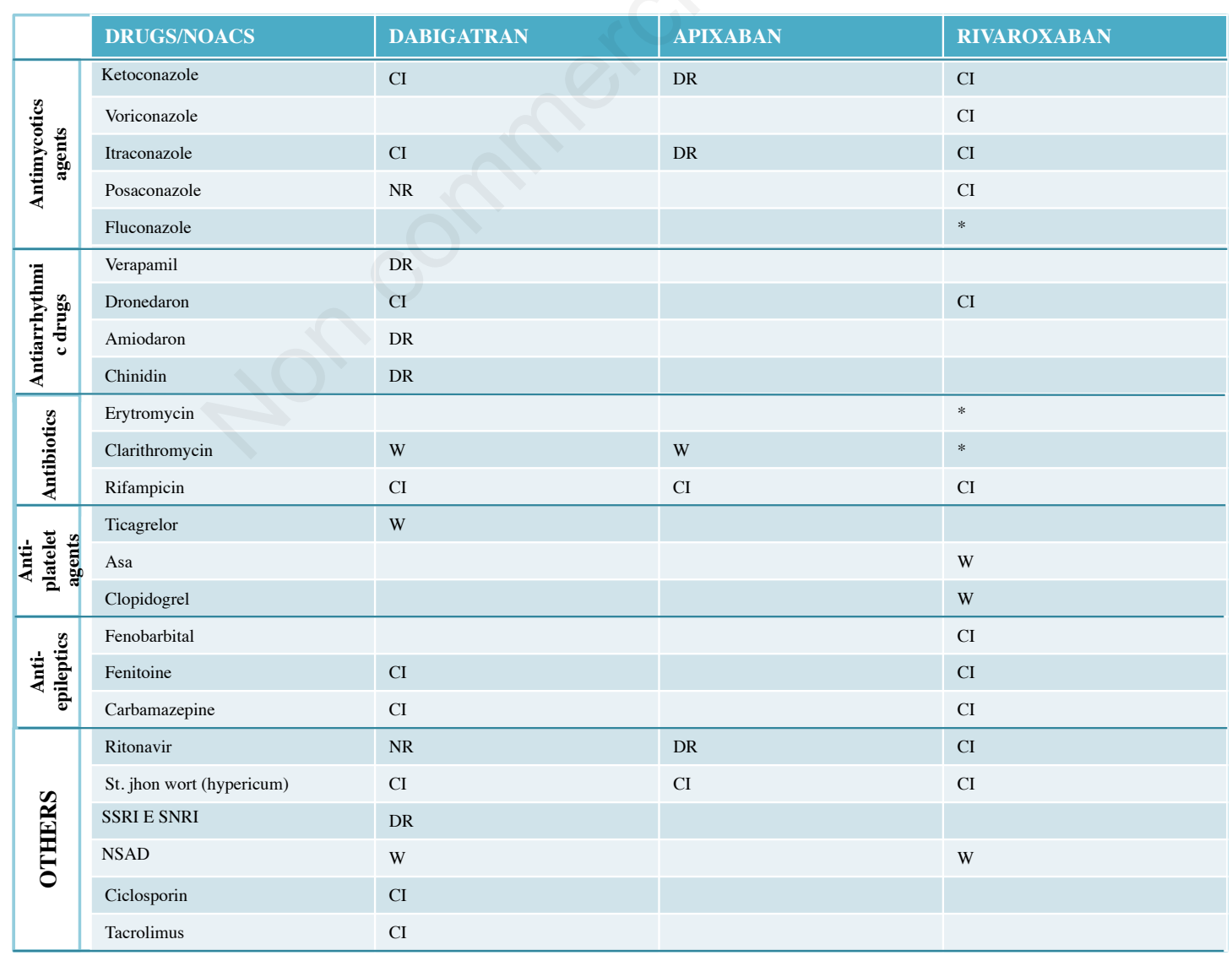

$\mathrm{CI}$, contraindicated; W, warning on safety; DR, dose reduction; *not clinically relevant rise in rivaroxaban activity.

Table A10. Drug interactions. 
- Fatal bleeding and/or

- Symptomatic bleeding in a critical area or organ:

- intracranial

- intraspinal

- retroperitoneal

- intraocular

- intrarticular

- intrapericardial

- intramuscular with compartment syndrome

and/or

- Bleeding causing:

- fall in hemoglobin level of $2 \mathrm{~g} / \mathrm{dl}$ or more or leading to transfusion of 2 or more units of whole blood or red cells

Table A11. Major bleeding definition.
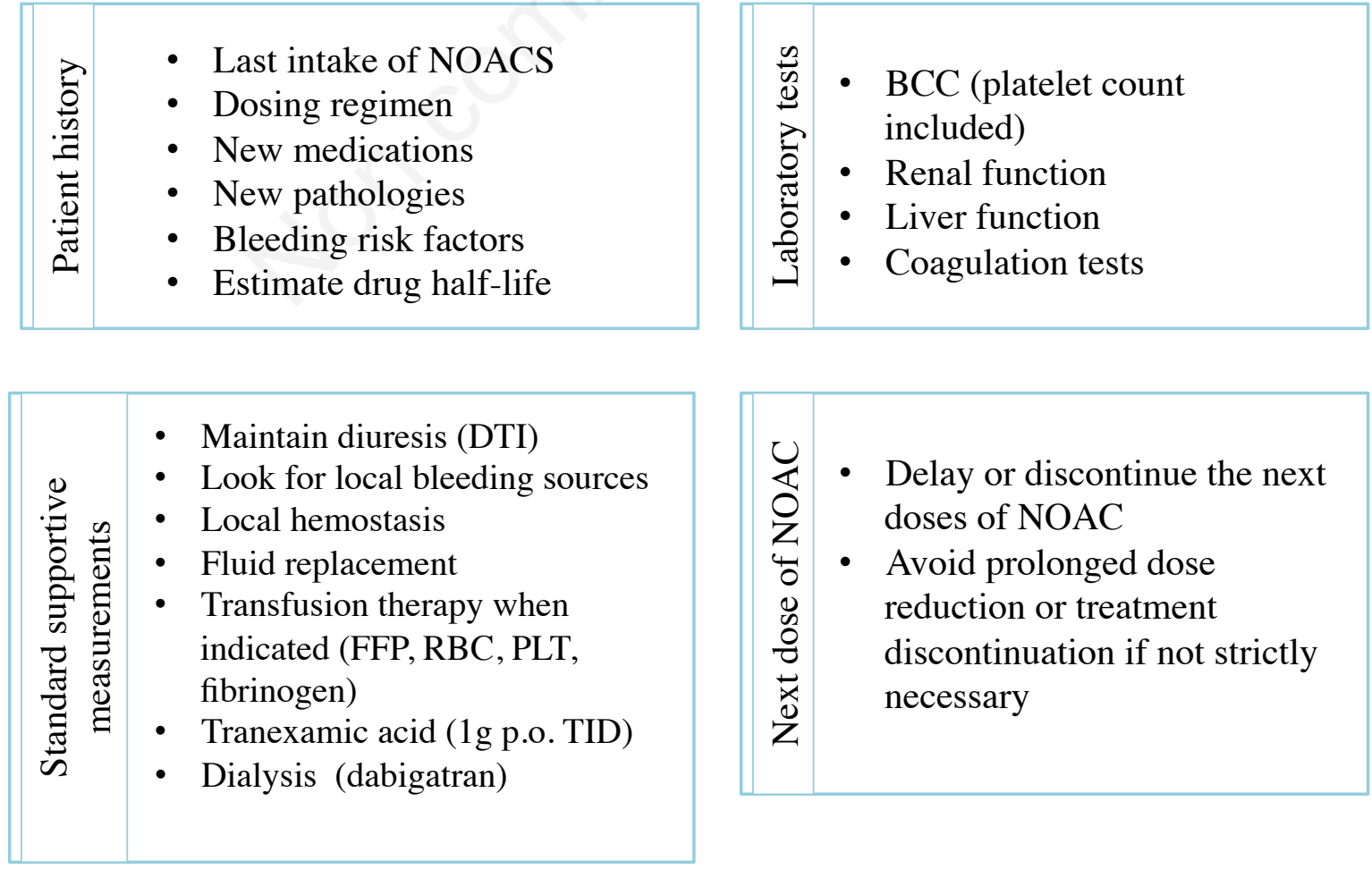

Table A12. Non-life-threatening major bleeding. 

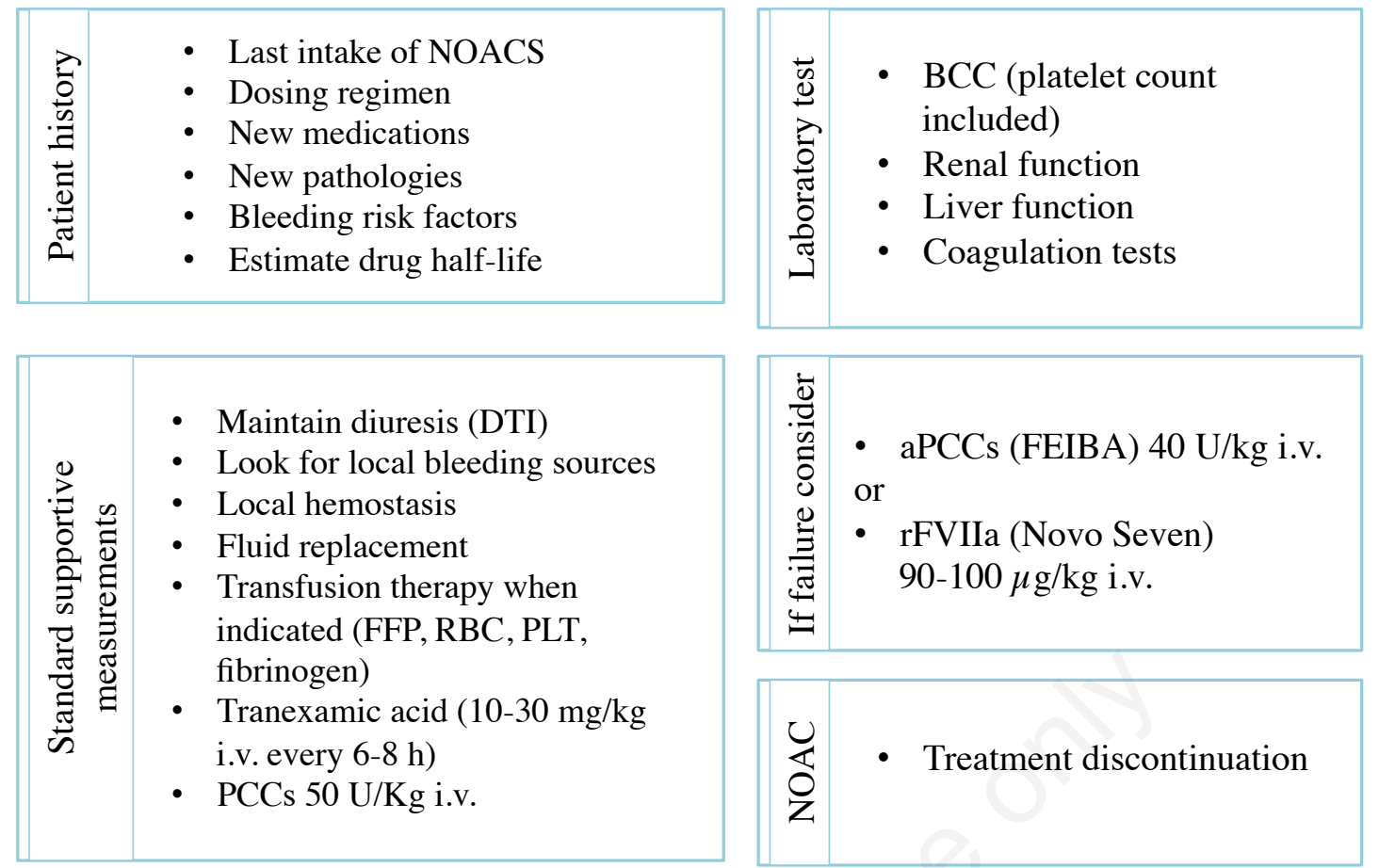

Table A13. Life-threatening major bleeding.

\begin{tabular}{|c|c|c|c|}
\hline & DABIGATRAN (D) & APIXABAN (A) & RIVAROXABAN (R) \\
\hline $\begin{array}{l}\text { FROM LMWH or } \\
\text { FONDAPARINUX }\end{array}$ & $\begin{array}{l}\text { - Discontinue LMWH } \\
\text { - Start D at the time the next dose } \\
\text { of LMWH would have been } \\
\text { administrated }\end{array}$ & $\begin{array}{l}\text { - Discontinue LMWH } \\
\text { - Start } \mathbf{A} \text { at the time the next dose } \\
\text { of LMWH would have been } \\
\text { administrated }\end{array}$ & $\begin{array}{l}\text { Start with the first dose of } \mathbf{R} 0-2 \\
\text { hours before prescribed next dose } \\
\text { of parenteral anticoagulant }\end{array}$ \\
\hline $\begin{array}{l}\text { TO LMWH or } \\
\text { FONDAPARINUX }\end{array}$ & $\begin{array}{l}\text { - Discontinue D } \\
\text { - Start LMWH at the time the } \\
\text { next scheduled dose }\end{array}$ & $\begin{array}{l}\text { - Discontinue A } \\
\text { - Start LMWH at the time the } \\
\text { next scheduled dose }\end{array}$ & $\begin{array}{l}\text { Start with the first dose of } \\
\text { parenteral anticoagulant when } \mathbf{R} \\
\text { should be administrated }\end{array}$ \\
\hline FROM VKA & $\begin{array}{l}\text { - Discontinue VKA and check } \\
\text { INR } \\
\text { - when INR }<2 \text { start the first } \\
\text { dose of } \mathbf{D}\end{array}$ & $\begin{array}{l}\text { Warfarin should be discontinued } \\
\text { and } \mathbf{A} \text { started when INR }<2\end{array}$ & $\begin{array}{l}\text { Stop warfarin at least two days } \\
\text { and acenocumarol at least one } \\
\text { day before introducing } \mathbf{R} \text {. } \\
\text { Check INR: } \\
\text { - INR } \leq 2 \text { start } R \text { immediately } \\
\text { - INR } 2-3 \text { start } R \text { the day after } \\
\text { - INR }>3 \text { re-check INR after } 2 \\
\text { days }\end{array}$ \\
\hline TO VKA & $\begin{array}{l}\text { Start VKA before } \mathbf{D} \text { is stopped. } \\
\text { Base the warfarin initiation on the } \\
\text { creatinine clearance }(\mathrm{CrCl}) \text { as } \\
\text { above: } \\
\text { - } \quad \mathrm{CrCl}>50 \mathrm{ml} / \mathrm{min} \text { stop D } \\
3 \text { days after starting VKA } \\
-\quad \mathrm{CrCl} 30-49 \mathrm{ml} / \mathrm{min} \text { stop D } \\
2 \text { days after starting VKA }\end{array}$ & $\begin{array}{l}\text { Start warfarin before } \mathbf{A} \text { is } \\
\text { stopped. } \\
\text { A affect INR, so INR testing } \\
\text { should be performed just before } \\
\text { the next intake of } \mathbf{A} \text {. } \\
\text { Consider also A discontinuation } \\
\text { and start LMWH and warfarin at } \\
\text { the time of the next dose of } \mathbf{A} \text {. } \\
\text { Stop LMWH when INR reaches } \\
\text { acceptable range. }\end{array}$ & $\begin{array}{l}\text { Start warfarin before } \mathbf{R} \text { is } \\
\text { stopped. } \\
\mathbf{R} \text { affect INR, so INR testing } \\
\text { should be performed just before } \\
\text { the next intake of } \mathbf{R} \text {. } \\
\text { Consider also } \mathbf{R} \text { discontinuation } \\
\text { and start LMWH and warfarin at } \\
\text { the time of the next dose of } \mathbf{R} \text {. } \\
\text { Stop LMWH when INR reaches } \\
\text { acceptable range. }\end{array}$ \\
\hline FROM UFH & $\begin{array}{l}\text { - Discontinue infusion of UFH } \\
\text { - Start D immediately with the } \\
\text { first dose of D }\end{array}$ & $\begin{array}{l}\text { A UHF can be initiated when the } \\
\text { next dose of } \mathrm{A} \text { is due }\end{array}$ & $\begin{array}{l}\mathbf{R} \text { can be started at the time of } \\
\text { UHF discontinuation }\end{array}$ \\
\hline TO UFH & $\begin{array}{l}\text { - Stop D } \\
\text { - Start UHF after } 12 \mathrm{~h} \text { from } \\
\text { UHF discontinuation }\end{array}$ & $\begin{array}{l}\text { UHF can be initiated when the } \\
\text { next dose of } \mathbf{A} \text { is due }\end{array}$ & $\begin{array}{l}\text { UHF can be initiated when the } \\
\text { next dose of } A \text { is due }\end{array}$ \\
\hline
\end{tabular}

Table A14. Switching to- and from-NOACs. Modified from Heidbuchel et al., $2013^{17}$ and Palareti et al., $2013 .{ }^{23}$ 